\title{
COVID-19 Vaccine and Hyperosmolar Hyperglycemic State
}

\author{
Mohammed A. Abu-Rumaileh ${ }^{1}$, Ahmad M. Gharaibeh ${ }^{1}$, Naser Eddin Gharaibeh ${ }^{2,} 3$ \\ 1. Endocrinology, University of Jordan School of Medicine, Amman, JOR 2. Endocrinology, Mercy Hospital Joplin, \\ Joplin, USA 3. Endocrinology, Kansas City University, Joplin, USA
}

Corresponding author: Mohammed A. Abu-Rumaileh, m_aburumaileh@yahoo.com

\begin{abstract}
Coronavirus disease 2019 (COVID-19) is a multi-system disease that causes multiple complications. It is linked to the development of new-onset diabetes or unmasking of underlying diabetes. Despite the uncertain exact mechanism, pancreatic angiotensin-converting enzyme 2 (ACE2) receptor, the main enzyme related to COVID-19 pathophysiology has been implied. COVID-19 vaccine was authorized to help control the rapid spread of COVID-19 disease. We report a case of new-onset diabetes type 2 presenting as hyperosmolar hyperglycemic state (HHS) in a patient after receiving COVID-19 vaccine with some literature review of the potential mechanisms by which COVID-19 may cause new-onset diabetes type 2 .
\end{abstract}

Categories: Endocrinology/Diabetes/Metabolism

Keywords: covid-19, covid-19 vaccine, hyperosmolar hyperglycemic state, type 2 diabetes, new-onset diabetes

\section{Introduction}

Coronavirus disease 2019 (COVID-19) is an infectious disease caused by the novel coronavirus, SARS-CoV-2. This virus was first identified in Wuhan, a city in the Hubei Province of China [1]. Its rapid spread in China has led to an epidemic, followed by a pandemic causing, until the present time, over 118 million cases and over 2.6 million deaths [2]. COVID-19 is a multi-system disease thought to be linked to development of new-onset diabetes [3]. The pressing need for a vaccine to help control this pandemic accelerated an Emergency Use Authorization (EUA) for Pfizer-BioNTech COVID-19 Vaccine in December 2020 [4]. We report a case of hyperosmolar hyperglycemic state (HHS) occurring post administration of Pfizer-BioNTech COVID19 Vaccine.

Review began 03/17/2021 Review ended 03/23/2021 Published 03/26/2021

\section{(๑) Copyright 2021}

Abu-Rumaileh et al. This is an open access article distributed under the terms of the Creative Commons Attribution License CC-BY 4.0., which permits unrestricted use, distribution, and reproduction in any medium, provided the original author and source are credited.

\section{Case Presentation}

A 58-year-old African male with a history of hypertension presented to the Emergency Room on 01/14/2021 complaining of progressive altered mental status of three days duration. The patient reported receiving his first Pfizer-BioNTech COVID-19 vaccine dose on 12/18/2020, after which he noticed increased nocturia to four times nightly, where he used to have nocturia only twice at night for the last few months, before the administration of the vaccine.

On 01/08/2021, the patient received his second Pfizer-BioNTech COVID-19 vaccine dose, two days afterwards, his nocturia significantly increased to around 12 times nightly. In addition, he noticed polyuria and polydipsia. He felt severely dehydrated and started drinking large amounts of fluids including 12 cans of regular soda and continued to have worsening mental status over the next three days. He lost 20 pounds in one-week period.

The patient denied any symptoms to suggest infection, such as hesitancy, urgency, or abdominal pain. He also denied cough, shortness of breath, fever, chills, or night sweats.

Upon presentation to the Emergency Room on 01/14/2021, the patient was drowsy, severely dehydrated, and disoriented. His blood pressure was $143 / 76 \mathrm{mmHg}$ with heart rate of 65 beats per minute, he was illappearing with mild tachypnea but no other significant findings.

His initial laboratory results showed serum glucose level of $1253 \mathrm{mg} / \mathrm{dL}$, bicarbonate level of $24 \mathrm{mmol} / \mathrm{L}$ with $\beta$-hydroxybutyrate level of $8.5 \mathrm{mmol} / \mathrm{L}$. Venous blood gas with other relevant laboratory results are shown in Tables $1,2$. 


\section{Cureus}

\begin{tabular}{|c|c|c|c|}
\hline Blood chemistry studies & Admission lab 01/14/2021 & 01/19/2021 & One-week post-discharge \\
\hline Sodium (136-145 mmol/L) & 144 & 140 & 133 \\
\hline Potassium (3.5-5.1 mmol/L) & 5.4 & 3.2 & 4.3 \\
\hline Chloride (98-107 mmol/L) & 95 & 105 & 104 \\
\hline Bicarbonate $(22-29 \mathrm{mmol} / \mathrm{L})$ & 24 & 25 & 20 \\
\hline Calcium (8.8-10.2 mmol/L) & 10.2 & 8.5 & 8.9 \\
\hline Blood urea nitrogen $(8-23 \mathrm{mmol} / \mathrm{L})$ & 60 & 19 & 13 \\
\hline Creatinine $(0.67-1.17 \mathrm{mg} / \mathrm{dL})$ & 1.95 & 1.13 & 1 \\
\hline Glomerular filtration rate ( $\mathrm{mL} / \mathrm{min} / 1.73 \mathrm{sq}$ meter) & 36 & $>60$ & $>60$ \\
\hline Glucose (74-99 mg/dL) & 1253 & 117 & 184 \\
\hline AST (0-40 U/L) & 33 & 54 & 35 \\
\hline ALT (0-41 U/L) & 62 & 55 & 49 \\
\hline Anion gap (4-13 mmol/L) & 25 & 10 & 9 \\
\hline \multicolumn{4}{|l|}{$\mathrm{CBC}$} \\
\hline Hemoglobin (13.5-18 g/dL) & 15.8 & 13.6 & 12.4 \\
\hline Platelets (1.5-4.5 x 105/L) & 127 & 54 & 183 \\
\hline WBC $\left(4.5-11.0 \times 10^{9} / \mathrm{L}\right)$ & 11.9 & 7.8 & 7.1 \\
\hline Neutrophils \% & 80 & 49 & 56 \\
\hline Lymphocytes \% & 16 & 43 & 35 \\
\hline
\end{tabular}

TABLE 1: Blood chemistry studies and CBC.

CBC: complete blood count; WBC: white blood cell; AST: aspartate transaminase; ALT: alanine aminotransferase. 


\section{Cureus}

\begin{tabular}{|c|c|}
\hline Venous blood gases & During hospitalization \\
\hline Specimen source & Venous \\
\hline pH blood (7.38-7.46) & 7.35 \\
\hline pCO2 (32-46 mmHg) & 47 \\
\hline Bicarbonate (21-29 mmol/L) & 26 \\
\hline pO2 (25-40 mmHg) & 25 \\
\hline O2 Sat & 42 \\
\hline TCO2 (22-31 mmol/L) & 27 \\
\hline Base excess (-2 - $2 \mathrm{mmol} / \mathrm{L})$ & 0 \\
\hline \multicolumn{2}{|l|}{ Miscellaneous } \\
\hline HBA1C (<=5.6\%) & 13 \\
\hline B-Hydroxybutyrate (<0.3 mmo//L) & 8.5 \\
\hline Glutamic acid decarboxylase anti-body ( $<=0.02 \mathrm{nmol} / \mathrm{L})$ & 0 \\
\hline Islet cell $A B(<=0.02 \mathrm{nmol} / \mathrm{L})$ & 0 \\
\hline C-peptide (1.10-4.40 ng/ml) & 1.1 \\
\hline Osmolality (275-300 mOsm/kg) & 371 \\
\hline TSH (0.27-4.2 ulU/ml) & 0.5 \\
\hline Vitamin D & 30 \\
\hline Troponin T, 5th Gen & 14 \\
\hline \multicolumn{2}{|l|}{ Lipid profile } \\
\hline Cholesterol (<200 mg/dL) & 239 \\
\hline HDL (40-59 mg/dL) & 54 \\
\hline LDL (<100mg/dL) & 128 \\
\hline Non-HDL Cholesterol (<130 mg/dL) & 185 \\
\hline Triglyceride (>150 mg/dL) & 285 \\
\hline
\end{tabular}

TABLE 2: Other labs.

TSH: thyroid-stimulating hormone; LDL: low-density lipoprotein; HDL: high-density lipoprotein.

The patient was admitted to the Intensive Care Unit, started on intravenous fluids with insulin drip. Next day, he was transitioned to multiple daily injections regimen and transferred to the floor for further management. His insulin regimen was up titrated and good glycemic control was achieved on insulin glargine 50 units once daily, in addition to 10 units of pre-meal insulin with correction scale.

PCR test was negative for COVID-19, Respiratory Syncytial Virus, and Influenza A, B. Chest x-ray was clear, EKG was normal, urine culture showed no growth.

The patient has family history of diabetes type 2 in both of his parents, he also has personal history of skin tags in his neck that started a few years ago, he reported that his diet was moderate in carbohydrates. Upon review of his chart, his fasting glucose has ranged from 74-120 in the last three years (Table 3). However, no baseline hemoglobin A1C was available. Four weeks after discharge, the dose of insulin was slowly tapered down then discontinued. The patient is currently only on metformin with excellent glycemic control, his fasting serum blood glucose level is $73 \mathrm{mg} / \mathrm{dL}$, with C-peptide level of $3.65 \mathrm{ng} / \mathrm{ml}$. 


\section{Cureus}

\begin{tabular}{|c|c|c|c|c|c|c|}
\hline Date & 08/24/2020 & 06/01/2020 & $02 / 11 / 2020$ & $02 / 06 / 2019$ & 11/14/2017 & 05/15/2017 \\
\hline Glucose (74-99 mg/dL) & 80 & 74 & 120 & 88 & 106 & 118 \\
\hline
\end{tabular}

TABLE 3: Previous serum blood glucose readings.

\section{Discussion}

Diabetes mellitus type 2 (DM-II) is a chronic disorder characterized by high blood glucose levels during a prolonged period of time. The natural history of DM-II starts with normal glucose tolerance with subsequent insulin resistance, hyperinsulinemia, then impaired glucose tolerance and finally DM-II [5].

HHS is a serious complication of DM-II, that can be fatal if untreated. Predisposing conditions include infection or inadequate insulin therapy. HHS results in extremely elevated glucose levels from inefficient insulin and mild elevation of counter-regulatory hormones (glucagon, catecholamines, cortisol, and growth hormone) that cause increased hepatic glucose production. Patients with HHS present with extreme thirst, frequent urination, confusion, weakness, and sometimes coma. HHS is diagnosed with blood glucose level above $600 \mathrm{mg} / \mathrm{dL}$, plasma osmolality >320, in the absence of significant ketoacidosis [6].

Hyperglycemia (typically with glucose level around $200 \mathrm{mg} / \mathrm{dl}$ ) causes glycosuria [7] which causes a net loss of water and dehydration. Severe dehydration and high serum osmolality are the main causes of altered mental status in patients at presentation [8]. HHS is characterized by inadequate insulin levels which will slightly increase lipolysis and ketogenesis, mechanisms through which blood ketone levels may mildly increase in patients with this condition [6].

A meta-analysis of eight different studies of nearly 3,700 patients revealed an average of $14.4 \%$ for newonset diabetes on admission in patients hospitalized with COVID-19 [9]. Similar results were found in a study of 453 patients admitted with COVID-19. Upon admission, $20.7 \%$ met the diagnostic criteria of newonset diabetes. Patients with new-onset diabetes on admission for COVID-19 were found to have a significant increase in mortality compared with patients with prediabetes or preexisting diabetes [10].

SARS-CoV-2 virus pathogenesis involves viral S protein utilization of cellular angiotensin-converting enzyme 2 (ACE2) receptor [11]. As ACE2 is expressed in key organs that regulate glucose metabolism such as pancreas, adipose tissue, and kidneys, it is thought that SARS-CoV-2 could impair glucose homeostasis [3]. In an experimental mice study, removal of ACE2 resulted in impairment of glucose homeostasis predisposing them to DM-II [12]. Studies documented that SARS-CoV-1 utilizes the ACE2 receptors and damages pancreatic $\beta$-cells causing acute diabetes [13].

Multiple studies confirmed the expression of ACE2 receptors in the $\beta$-cells of pancreas making them prone to SARS-CoV-2 infection [11]. Entry of SARS-CoV-2 into pancreatic $\beta$-cells was detected in vitro, indicating possible destruction of pancreatic cells upon entry of the virus [14].

Renin-angiotensin system (RAS) is an enzyme system cascade that produces angiotensin II which promotes vasoconstriction, oxidative stress, inflammation, in addition to salt and water reabsorption [15]. ACE2 metabolizes angiotensin II, thereby down-regulating the activity of RAS pathway [16].

RAS components were found in several tissues including pancreas, liver, and muscles. RAS hyperactivity decreases perfusion of the pancreatic tissue and reduces insulin production, and increases oxidative stress resulting in fibrosis. Also, it decreases insulin sensitivity on target tissues [17]. SARS-CoV viral entry to ACE2 expressing cells causes down-regulation of ACE2 which increases RAS pathway activity [18], possibly causing worsened insulin resistance and decreased insulin release [17]. Interestingly, ACE2 receptors are expressed on the surface of macrophages [19]. Infection of islet macrophages may impair pancreatic $\beta$-cells function [20].

\section{Conclusions}

While Pfizer-BioNTech COVID-19 vaccine appears to be relatively safe, the vaccine might trigger an immune response that may have unmasked the patient's underlying pre-diabetes. As of the time of writing this report, no cases of new-onset diabetes after COVID-19 vaccine were found in the literature. Based on this report, regulatory bodies should consider close monitoring of COVID-19 vaccines effect on metabolic profile including the risk of new-onset DM-II. In addition, prompt screening for DM-II in susceptible patients following administration of COVID-19 vaccine should be considered by treating providers.

\section{Additional Information}




\section{Disclosures}

Human subjects: Consent was obtained or waived by all participants in this study. Conflicts of interest: In compliance with the ICMJE uniform disclosure form, all authors declare the following: Payment/services info: All authors have declared that no financial support was received from any organization for the submitted work. Financial relationships: All authors have declared that they have no financial relationships at present or within the previous three years with any organizations that might have an interest in the submitted work. Other relationships: All authors have declared that there are no other relationships or activities that could appear to have influenced the submitted work.

\section{References}

1. Munster VJ, Koopmans M, van Doremalen N, van Riel D, de Wit E: A novel coronavirus emerging in China key questions for impact assessment. N Engl J Med. 2020, 382:692-694. 10.1056/NEJMp2000929

2. WHO Coronavirus Disease (COVID-19) Dashboard. World Health Organization. . (2021). Accessed: February 12, 2021: https://covid19.who.int/.

3. Rubino F, Amiel SA, Zimmet P, et al.: New-onset diabetes in COVID-19. N Engl J Med. 2020, 383:789-790. 10.1056/NEJMc2018688

4. EtR for Pfizer-BioNTech COVID-19 Vaccine under EUA. Centers for Disease Control and Prevention . (2020). Accessed: February 12, 2021: https://www.cdc.gov/vaccines/acip/recs/grade/covid-19-pfizer-biontechetr.html.

5. DeFronzo RA: Pathogenesis of type 2 diabetes mellitus. Med Clin North Am. 2004, 88:787-835. 10.1016/j.mcna.2004.04.013

6. Pasquel FJ, Umpierrez GE: Hyperosmolar hyperglycemic state: a historic review of the clinical presentation, diagnosis, and treatment. Diabetes Care. 2014, 37:3124-3131. 10.2337/dc14-0984

7. Rahhal MN, Gharaibeh NE, Rahimi L, Ismail-Beigi F: Disturbances in insulin-glucose metabolism in patients with advanced renal disease with and without diabetes. J Clin Endocrinol Metab. 2019, 104:4949-4966. 10.1210/jc.2019-00286

8. Umpierrez GE, Kelly JP, Navarrete JE, Casals MM, Kitabchi AE: Hyperglycemic crises in urban blacks . Arch Intern Med. 1997, 157:669-675. 10.1001/archinte.1997.00440270117011

9. Sathish T, Kapoor N, Cao Y, Tapp RJ, Zimmet P: Proportion of newly diagnosed diabetes in COVID-19 patients: a systematic review and meta-analysis. Diabetes Obes Metab. 2021, 23:870-874. 10.1111/dom.14269

10. Li H, Tian S, Chen T, et al.: Newly diagnosed diabetes is associated with a higher risk of mortality than known diabetes in hospitalized patients with COVID-19. Diabetes Obes Metab. 2020, 22:1897-1906. 10.1111/dom.14099

11. Müller JA, Groß R, Conzelmann C, et al.: SARS-CoV-2 infects and replicates in cells of the human endocrine and exocrine pancreas. Nat Metab. 2021, 3:149-165. 10.1038/s42255-021-00347-1

12. Niu MJ, Yang JK, Lin SS, Ji XJ, Guo LM: Loss of angiotensin-converting enzyme 2 leads to impaired glucose homeostasis in mice. Endocrine. 2008, 34:56-61. 10.1007/s12020-008-9110-X

13. Yang JK, Lin SS, Ji XJ, Guo LM: Binding of SARS coronavirus to its receptor damages islets and causes acute diabetes. Acta Diabetol. 2010, 47:193-199. 10.1007/s00592-009-0109-4

14. Yang L, Han Y, Nilsson-Payant BE, et al.: A human pluripotent stem cell-based platform to study SARSCoV-2 tropism and model virus infection in human cells and organoids. Cell Stem Cell. 2020, 27:125-136.e7. 10.1016/j.stem.2020.06.015

15. Benigni A, Cassis P, Remuzzi G: Angiotensin II revisited: new roles in inflammation, immunology and aging. EMBO Mol Med. 2010, 2:247-257. 10.1002/emmm.201000080

16. Rice GI, Thomas DA, Grant PJ, Turner AJ, Hooper NM: Evaluation of angiotensin-converting enzyme (ACE), its homologue ACE2 and neprilysin in angiotensin peptide metabolism. Biochem J. 2004, 383:45-51. 10.1042/BJ20040634

17. Bindom SM, Lazartigues E: The sweeter side of ACE2: physiological evidence for a role in diabetes . Mol Cell Endocrinol. 2009, 302:193-202. 10.1016/j.mce.2008.09.020

18. Kuba K, Imai Y, Rao S, et al.: A crucial role of angiotensin converting enzyme 2 (ACE2) in SARS coronavirus-induced lung injury. Nat Med. 2005, 11:875-879. 10.1038/nm1267

19. Rutkowska-Zapała M, Suski M, Szatanek R, et al.: Human monocyte subsets exhibit divergent angiotensin Iconverting activity. Clin Exp Immunol. 2015, 181:126-132. 10.1111/cei.12612

20. Ying W, Lee YS, Dong Y, et al.: Expansion of Islet-Resident Macrophages Leads to Inflammation Affecting $\beta$ Cell Proliferation and Function in Obesity. Cell Metab. 2019, 29:457-474.e5. 10.1016/j.cmet.2018.12.003 